Pleione 14(2): 293 - 299. 2020.

(C) East Himalayan Society for Spermatophyte Taxonomy

doi:10.26679/Pleione.14.2.2020.293-299

\title{
Plant based raw drugs sold in the markets of the Darjeeling Himalaya, India: A case study
}

\author{
Upakar Rai ${ }^{1,3}$ and Barkha Rai ${ }^{2}$ \\ ${ }^{1}$ Department of Botany, ${ }^{2}$ Department of Zoology St. Joseph's College, North Point 734104, Darjeeling, \\ West Bengal, India \\ ${ }^{3}$ Corresponding author, e-mail: upakar@yahoo.ocm
}

[Received 15.11.2020; Revised 22.12.2020; Accepted 23.12.2020; Published 31.12.2020]

\begin{abstract}
Plant based raw drugs are inexpensive and readily available, which are integral part of the local health care system of Darjeeling Himalaya, India. These drugs are widely used for treating common ailments and injuries without any side effects, and are prevalent in the hill regions of the Darjeeling district. Present study is the outcome of oral interviews of three sellers in Darjeeling town to record the taxonomic identity, parts used, its uses and the mode of administration of these proven ethno-medico botanical resource available in the market.
\end{abstract}

Key words: Raw drugs, Darjeeling hills, ethno-medicine, healthcare system

\section{INTRODUCTION}

Plants have been used in the traditional healthcare system from time immemorial. Numerous wild and cultivated plants play a vital role in cultural and traditional healthcare system of local poor inhabitants in the hill regions. Practice of herbal treatment evolved over generations of experience and practice, and the information passed through verbal communications. Herbal medicines are becoming popular worldwide due to its growing recognition of natural products being cheaper and without much side effects (Anonymous 2009).

Out of the 20,000 medicinal plants listed by the WHO globally, India is one of the richest centers of medicinal plant resources and contributes $15-20 \%$ of the total species (Anonymous 2009; Hamilton \& Radford 2007). At present, there is a worldwide movement for assessing the plant resources and researches for new plants which have medicinal and economical value. Researchers are not only focusing on ethnobotanical and ethnomedicinal investigation, but also studying to assess their population in the wild to fulfill the increasing demand of herbal products (Anonymous 2009; Rai 2010).

Darjeeling Himalaya has rich tradition of ethno-medicine because of large number of indigenous ethnic groups. These people have in-depth understanding about plants - for food and medicine because they largely survive on the forest resources for their daily life. Ethnomedicinal practices based on local plant resources like Jari-butti, Amchi, etc. due to inadequate public health centers across the hills are still underuse (Chhetri et al. 2005; Ghosh \& Tripathi 2019).

The Nepali system of medicine has wider base, however, the traditional system of medicine has no organized set up in in India. At present the system survives at the peddler's level with small stalls in the market place with subsistence income. Therefore, there is a need to explore the current ethnomedicinal practices available in the region. The present study aims to document various species of medicinal plant sold in Darjeeling town as raw drugs.

\section{MATERIALS AND METHODS}

The study was conducted in Darjeeling town to document the plant based raw drugs. The local sellers were interviewed through structured questionnaire. Information like local name, 
uses, mode of administration was gathered directly from the sellers. Photograph of the sample were taken for authentication. Samples were identified in the Department of Botany, St. Joseph's College and with the help of local floras (Cowan \& Cowan 1929; Gierson \& Long 1984, 1987, 1991, 1999) and other medicinal plant related literatures (Gurung 2002; Das \& Mandal 2003). The updated nomenclature and family delimitation was done as per www.plantsoftheworldonline.org and www.theplantlist.org.

\section{RESULT}

A total of 36 species of plant based raw drugs belonging to 25 families are sold for treating various ailments. Among these, plants belonging to family Leguminosae with five species was the largest family followed by Combretaceae and Zingiberaceae with three species each, Ranunculaceae, Apocynaceae and Malvaceae with two species each and remaining nineteen families are represented by single species. Botanical names, local names, families, parts used, uses and mode of administration are provided in Table 1.

Table 1. Names of the plant based raw drugs, their taxonomic status, parts used, uses and mode of administration

\begin{tabular}{|c|c|c|c|c|}
\hline Scientific name & Local name & Parts used & Uses & Mode of administration \\
\hline $\begin{array}{l}\text { Acacia catechu (L.f.) Willd. } \\
\text { [Leguminosae] }\end{array}$ & Khayer & $\begin{array}{l}\text { Stem/heart } \\
\text { wood }\end{array}$ & $\begin{array}{l}\text { Muscular pain and } \\
\text { injuries }\end{array}$ & Cooked with milk \\
\hline $\begin{array}{l}\text { Aconitum heterophyllum } \\
\text { Wall. ex Royle [Ranunculaceae] }\end{array}$ & Kalo bikuma & Rhizome & $\begin{array}{l}\text { Used in rheumatism } \\
\text { fever and body pain. }\end{array}$ & $\begin{array}{l}\text { Powder soaked in water } \\
\text { or boiled }\end{array}$ \\
\hline $\begin{array}{l}\text { Acorus calamus L. } \\
\text { [Acoraceae] }\end{array}$ & Bojho & Rhizome & $\begin{array}{l}\text { Used in fever, sudden } \\
\text { muscle pain; also used } \\
\text { as an insect repellent }\end{array}$ & Roots chewed raw \\
\hline $\begin{array}{l}\text { Allium wallichii Kunth } \\
\text { [Amaryllidaceae] }\end{array}$ & Ban Lasun & Bulb & $\begin{array}{l}\text { Bulb useful in the } \\
\text { treatment of cholera } \\
\text { and dysentery; reduce } \\
\text { blood cholesterol } \\
\text { levels and acts as a } \\
\text { tonic }\end{array}$ & $\begin{array}{l}\text { bulb is boiled and then } \\
\text { fried in ghee, and } \\
\text { consumed }\end{array}$ \\
\hline $\begin{array}{l}\text { Asparagus racemosus Willd. } \\
\text { [Asparagaceae] }\end{array}$ & Satawari & $\begin{array}{l}\text { Tuberous } \\
\text { root }\end{array}$ & $\begin{array}{l}\text { Used as diuretic for } \\
\text { the treatment of } \\
\text { dysentery, diarrhea, } \\
\text { blood diseases, liver } \\
\text { leprosy, epilepsy, night } \\
\text { blindness, rheumatism } \\
\text { and gonorrhea }\end{array}$ & $\begin{array}{l}\text { Boiled with water and } \\
\text { consumed }\end{array}$ \\
\hline $\begin{array}{l}\text { Astilbe rivularis Buch.-Ham. } \\
\text { ex D.Don [Saxifragaceae] }\end{array}$ & Bodo okhati & Rhizome & $\begin{array}{l}\text { It is used as a blood } \\
\text { purifier; also useful in } \\
\text { diarrhea and dysentery }\end{array}$ & $\begin{array}{l}\text { The root can be chewed } \\
\text { raw or boil in milk and } \\
\text { consume }\end{array}$ \\
\hline $\begin{array}{l}\text { Clematis buchananiana DC. } \\
\text { [Ranunculaceae] }\end{array}$ & Pinashey lahara & $\begin{array}{l}\text { Roots and } \\
\text { aerial parts }\end{array}$ & $\begin{array}{l}\text { It is used to cure } \\
\text { sinusitis, also an } \\
\text { antiviral }\end{array}$ & $\begin{array}{l}\text { Roots roasted and smoke } \\
\text { inhaled }\end{array}$ \\
\hline $\begin{array}{l}\text { Curcuma zedoaria (Christm.) } \\
\text { Roscoe [Zingiberaceae] }\end{array}$ & Kalo Hardi & Rhizome & $\begin{array}{l}\text { It is useful in food } \\
\text { poisoning }\end{array}$ & $\begin{array}{l}\text { Chewed raw or boiled in } \\
\text { water or milk and the } \\
\text { liquid is consumed }\end{array}$ \\
\hline $\begin{array}{l}\text { Dactylorhiza hatagirea } \\
\text { (D.Don) Soo [Orchidaceae] }\end{array}$ & Panch aule & Tuber & $\begin{array}{l}\text { It is used for body- } \\
\text { ache, cuts and bruises }\end{array}$ & $\begin{array}{l}\text { Dried tuber grind and } \\
\text { mixed with milk and } \\
\text { taken }\end{array}$ \\
\hline $\begin{array}{l}\text { Entada gigas (L.) Fawc. \& } \\
\text { Rendel [Leguminosae] }\end{array}$ & Pangra & Seed & $\begin{array}{l}\text { It causes vomiting, } \\
\text { also used as an } \\
\text { astringent that } \\
\text { contracts body tissues } \\
\text { and mums }\end{array}$ & $\begin{array}{l}\text { Seed is grind and } \\
\text { consumed }\end{array}$ \\
\hline
\end{tabular}



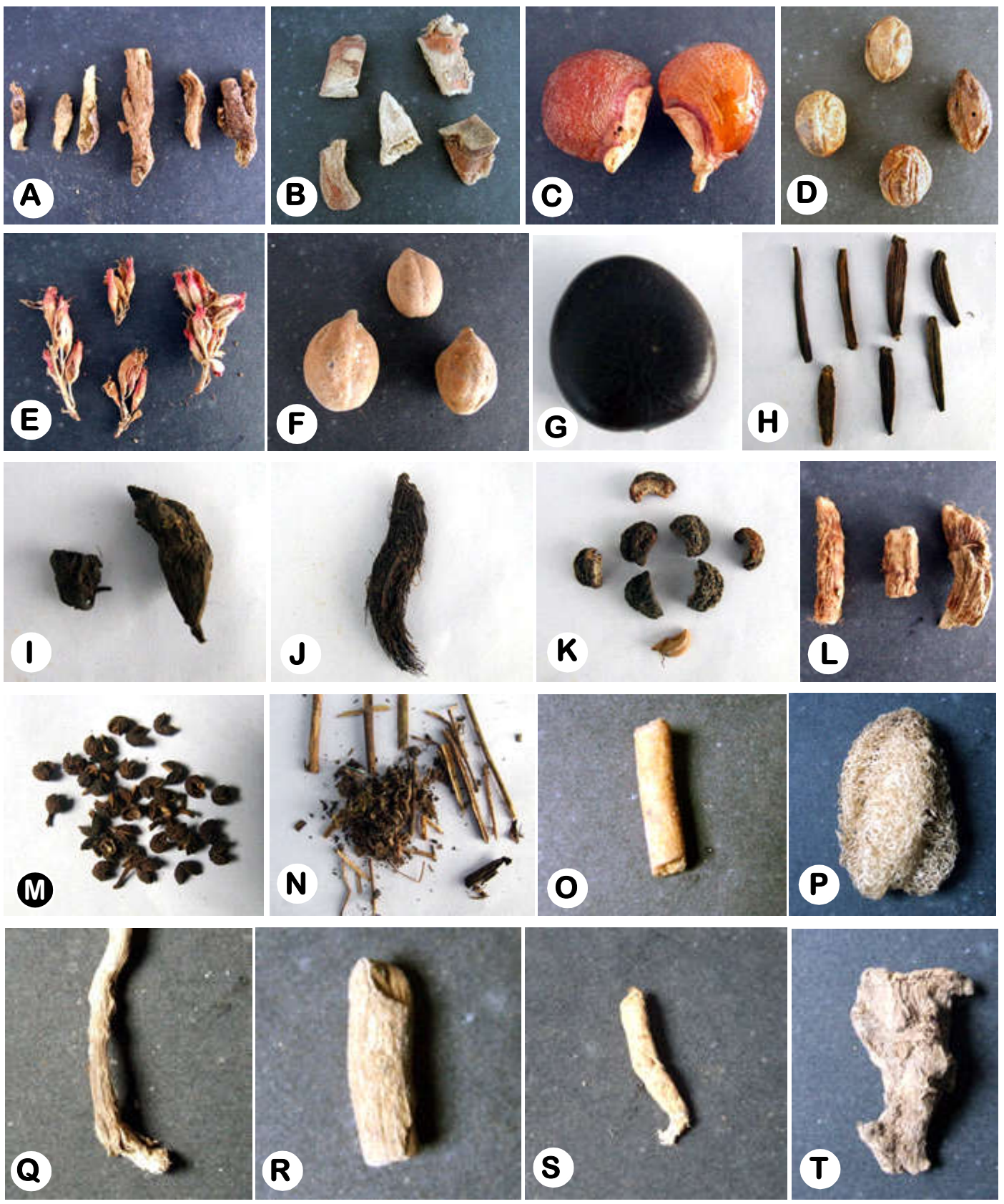

PLATE - I. Marketed raw drugs in Darjeeling: A. Stem of Glycyrrhiza glabra; B. Root-stock of Piper betle; C. Fruits of Sapindus mukorossi; D. Fruits of Terminalia chebula; E. Flowers of Woodfordia fruticosa; F. Fruits of Terminalia bellirica; G. A seed of Entada gigas; H. Stem (phyloclad) of Viscum articulatum; I. Root of Aconitum heterophyllum; J. Root of Nardostachys jatamansi; K. Pericarp of Phyllanthus emblica; L. Rhizome of Acorus calamus; M. Fruits of Zanthoxylum armatum; N. Arial parts of Swertia chirayita; O. Tuberous root of Asparagus racemosus; P. Fibrous mesocarp of Luffa operculata; Q. Root of Clematis buchananiana; R. Root of Rauvolfia serpentina; S. Root of Withania somnifera; T. Rhizome of Curcuma aromatica. 


\begin{tabular}{|c|c|c|c|c|}
\hline Scientific name & Local name & Parts used & Uses & Mode of administration \\
\hline $\begin{array}{l}\text { Fraxinus floribunda Wall. } \\
\text { [Oleaceae] }\end{array}$ & Lakuri & Bark & $\begin{array}{l}\text { It is useful in curing } \\
\text { rheumatism and gout }\end{array}$ & $\begin{array}{l}\text { Root and barks is chewed } \\
\text { raw or boiled in water and } \\
\text { consumed }\end{array}$ \\
\hline $\begin{array}{l}\text { Glycyrrhiza glabra L. } \\
\text { [Leguminosae] }\end{array}$ & Jethi madhu & Roots & $\begin{array}{l}\text { Used in cough, fever, } \\
\text { urinary tract infection } \\
\text { and sub-acute } \\
\text { pharyngitis }\end{array}$ & Roots chewed raw \\
\hline Helicteres isora L. [Malvaceae] & Mrigasinga & $\begin{array}{l}\text { Fruit and } \\
\text { Bark }\end{array}$ & $\begin{array}{l}\text { Fried pods used as } \\
\text { anti-helminthic. Bark } \\
\text { used in diarrhea and } \\
\text { dysentery }\end{array}$ & $\begin{array}{l}\text { Fruit pods fried and } \\
\text { taken. Decoction of bark } \\
\text { is used for the treatment }\end{array}$ \\
\hline $\begin{array}{l}\text { Hibiscus sabdariffa L. } \\
\text { [Malvaceae] }\end{array}$ & Lal chan & Flower & $\begin{array}{l}\text { It is also used in } \\
\text { dysentery and diarrhea }\end{array}$ & $\begin{array}{l}\text { Decoction of floral part } \\
\text { taken }\end{array}$ \\
\hline $\begin{array}{l}\text { Kaempferia rotunda L. } \\
\text { [Zingiberaceae] }\end{array}$ & Bhui champa & Bulb & $\begin{array}{l}\text { It is useful in setting } \\
\text { bone fractures }\end{array}$ & $\begin{array}{l}\text { The paste of the bulb is } \\
\text { applied to the affected } \\
\text { part }\end{array}$ \\
\hline $\begin{array}{l}\text { Luffa operculata (L.) Cogn. } \\
\text { [Cucurbitaceae] }\end{array}$ & Ban Toria & Fruit & $\begin{array}{l}\text { It is used to cure } \\
\text { Jaundice, diabetes }\end{array}$ & $\begin{array}{l}\text { The dried seed is grind } \\
\text { and decoction taken twice } \\
\text { in the morning and } \\
\text { evening before food }\end{array}$ \\
\hline $\begin{array}{l}\text { Macrotyloma uniflorum } \\
\text { (Lam.) Verdc. [Leguminosae] }\end{array}$ & Gahat & Seeds & $\begin{array}{l}\text { It helps in curing } \\
\text { measles, chicken pox, } \\
\text { tumors and asthma }\end{array}$ & $\begin{array}{l}\text { Boiled in water and } \\
\text { cooled water taken }\end{array}$ \\
\hline $\begin{array}{l}\text { Nardostachys jatamansi } \\
\text { (D.Don) DC. [Caprifoliaceae] }\end{array}$ & Jatamasi & Whole plant & $\begin{array}{l}\text { Used as heart tonic, } \\
\text { laxative, skin diseases, } \\
\text { leprosy, ulcers; helpful } \\
\text { in improving } \\
\text { urination, } \\
\text { menstruation and } \\
\text { digestion }\end{array}$ & Root is eaten raw \\
\hline $\begin{array}{l}\text { Neopicrorhiza } \\
\text { scrophulariflora (Pennell) D.Y. } \\
\text { Hong [Plantaginaceae] }\end{array}$ & Kutki & Root & $\begin{array}{l}\text { It is used as blood } \\
\text { purifier, appetizer, } \\
\text { laxative; also used in } \\
\text { dropsy, jaundice and } \\
\text { bile trouble }\end{array}$ & $\begin{array}{l}\text { Roots are boiled in water } \\
\text { or milk and consumed }\end{array}$ \\
\hline $\begin{array}{l}\text { Phyllanthus emblica L. } \\
\text { [Phyllanthaceae] }\end{array}$ & Amala & Friut & $\begin{array}{l}\text { Used as laxative, liver } \\
\text { tonic, in cough, } \\
\text { indigestion, } \\
\text { constipation, diarrhea } \\
\text { and dysentery }\end{array}$ & $\begin{array}{l}\text { Either the fruits are } \\
\text { consumed raw or to be } \\
\text { boiled with water and } \\
\text { consumed }\end{array}$ \\
\hline Piper betle L. [Piperaceae] & Pan ko Jara & Root & $\begin{array}{l}\text { It is usually used in } \\
\text { cough, sore throat }\end{array}$ & Roots chewed raw \\
\hline $\begin{array}{l}\text { Rauvolfia serpentina (L.) } \\
\text { Benth. ex Kurtz [Apocynaceae] }\end{array}$ & Sarpagandha & Roots & $\begin{array}{l}\text { Used in high blood } \\
\text { pressure, antidote for } \\
\text { snake bite, epilepsy } \\
\text { and insomnia }\end{array}$ & $\begin{array}{l}\text { Root boiled in water and } \\
\text { consumed. In case of } \\
\text { epilepsy it is applied to } \\
\text { eye lid }\end{array}$ \\
\hline $\begin{array}{l}\text { Rhododendron arboreum } \mathrm{Sm} \text {. } \\
\text { [Ericaceae] }\end{array}$ & Laliguras & Flower & $\begin{array}{l}\text { Used in dysentery and } \\
\text { diarrhea }\end{array}$ & $\begin{array}{l}\text { Fresh or dried flowers to } \\
\text { be consumed raw }\end{array}$ \\
\hline $\begin{array}{l}\text { Sapindus mukorossi Gaertn. } \\
\text { [Sapindaceae] }\end{array}$ & Ritha & Fruit & $\begin{array}{l}\text { Fruit juice is used as } \\
\text { hair conditioner and is } \\
\text { also used to cure } \\
\text { burnt parts of the } \\
\text { body }\end{array}$ & $\begin{array}{l}\text { The fruit is rubbed in } \\
\text { water to form lather and } \\
\text { then used }\end{array}$ \\
\hline $\begin{array}{l}\text { Saraca indica L. } \\
\text { [Leguminosae] }\end{array}$ & Ashok Chal & Bark of root & $\begin{array}{l}\text { Some of the ailments } \\
\text { of women (uterine } \\
\text { disorder) can be cured } \\
\text { from the juice } \\
\text { obtained from the } \\
\text { bark; pulp of the }\end{array}$ & $\begin{array}{l}\text { The bark is boiled with } \\
\text { water and consumed }\end{array}$ \\
\hline
\end{tabular}


Upakar Rai \& Barkha Rai 297

\begin{tabular}{|c|c|c|c|c|}
\hline Scientific name & Local name & Parts used & Uses & Mode of administration \\
\hline $\begin{array}{l}\text { Saraca indica L. } \\
\text { [Leguminosae] (contd.) }\end{array}$ & & & $\begin{array}{l}\text { blossom can also be } \\
\text { used as a remedy for } \\
\text { dysentery and diabetes } \\
\text { and internal piles }\end{array}$ & \\
\hline $\begin{array}{l}\text { Stephania glabra (Roxb.) } \\
\text { Miers [Menispermaceae] }\end{array}$ & Taubarkey & Root bulb & $\begin{array}{l}\text { powder of the root is } \\
\text { used to treat diabetes, } \\
\text { tuberculosis, asthma } \\
\text { and fever }\end{array}$ & $\begin{array}{l}\text { Bulb boiled in water and } \\
\text { consumed }\end{array}$ \\
\hline $\begin{array}{l}\text { Swertia chirayita (Roxb.) } \\
\text { Buch.-Ham. ex C.B. Clarke } \\
\text { [Gentianaceae] }\end{array}$ & Chirauto & whole plant & $\begin{array}{l}\text { It is used as a tonic in } \\
\text { skin diseases, chronic } \\
\text { fever and leucoderma, } \\
\text { cough, cold, diarrhea, } \\
\text { stomach ache }\end{array}$ & $\begin{array}{l}\text { The plant is boiled with } \\
\text { water and consumed }\end{array}$ \\
\hline $\begin{array}{l}\text { Terminalia arjuna (Roxb. ex } \\
\text { DC) Wight \& Arn. } \\
\text { [Combretaceae] }\end{array}$ & Arjun chal & $\begin{array}{l}\text { Bark and } \\
\text { fruit }\end{array}$ & $\begin{array}{l}\text { Preparation of bark } \\
\text { and fruit used as } \\
\text { cardiac tonic, } \\
\text { astringent and } \\
\text { febrifuge; useful in } \\
\text { blood dysentery, } \\
\text { blood pressure } \\
\text { leucorrhea }\end{array}$ & $\begin{array}{l}\text { Becoction of bark mixed } \\
\text { with milk and honey and } \\
\text { consumed every morning } \\
\text { in an empty stomach }\end{array}$ \\
\hline $\begin{array}{l}\text { Terminalia bellirica (Gaertn.) } \\
\text { Roxb. [Combretaceae] }\end{array}$ & Barra & Fruit, Bark & $\begin{array}{l}\text { Fruits used as to cure } \\
\text { piles, diarrhea, cough, } \\
\text { sore-throat; bark used } \\
\text { for anemia and } \\
\text { leucoderma }\end{array}$ & $\begin{array}{l}\text { Fruit grind into powder, } \\
\text { boil with water and taken }\end{array}$ \\
\hline $\begin{array}{l}\text { Terminalia chebula Retz. } \\
\text { [Combretaceae] }\end{array}$ & Harra & Fruit & $\begin{array}{l}\text { Used as a cardiac tonic } \\
\text { and various ailments } \\
\text { like asthma, diarrhea, } \\
\text { dysentery blood } \\
\text { pressure and piles }\end{array}$ & $\begin{array}{l}\text { Fruit grind into powder, } \\
\text { boil with water and } \\
\text { consume }\end{array}$ \\
\hline $\begin{array}{l}\text { Viscum articulatum Burm.f. } \\
\text { [Santalaceae] }\end{array}$ & Harcbur & whole plant & $\begin{array}{l}\text { Bone fractures, } \\
\text { muscular pains and } \\
\text { injuries }\end{array}$ & $\begin{array}{l}\text { Powder Mix with milk } \\
\text { boil and consume }\end{array}$ \\
\hline $\begin{array}{l}\text { Withania somnifera (L.) } \\
\text { Dunal. [Solanaceae] }\end{array}$ & Aswagandha & Roots & $\begin{array}{l}\text { Used as aphrodisiac, } \\
\text { tonic, rheumatism and } \\
\text { health tonic }\end{array}$ & $\begin{array}{l}\text { Roots powder mixed with } \\
\text { milk, ghee and honey, boil } \\
\text { and consume }\end{array}$ \\
\hline $\begin{array}{l}\text { Woodfordia fruticosa (L.) } \\
\text { Kurz [Lythraceae] }\end{array}$ & Dhuaro Phul & Flower & $\begin{array}{l}\text { It is used in dysentery } \\
\text { and diarrhea }\end{array}$ & $\begin{array}{l}\text { Dried flower consumed } \\
\text { raw or decoction taken }\end{array}$ \\
\hline $\begin{array}{l}\text { Wrightia tinctoria R.Br. } \\
\text { [Apocynaceae] }\end{array}$ & Indra Jaaw & Fruit & $\begin{array}{l}\text { It is used to cure } \\
\text { diabetes, high blood } \\
\text { pressure }\end{array}$ & $\begin{array}{l}\text { Soaked fruit juice taken } \\
\text { every morning in empty } \\
\text { stomach }\end{array}$ \\
\hline $\begin{array}{l}\text { Zanthoxylum armatum DC. } \\
\text { [Rutaceae] }\end{array}$ & Jat timbur & Fruit & $\begin{array}{l}\text { Useful in gastric } \\
\text { problems and other } \\
\text { stomach problems }\end{array}$ & Fruits taken raw \\
\hline $\begin{array}{l}\text { Curcuma aromatica } \text { Salisb. } \\
\text { [Zingiberaceae] }\end{array}$ & Phachyeng & Rhizome & $\begin{array}{l}\text { It is effective in } \\
\text { jaundice, skin diseases, } \\
\text { diarrhea and } \\
\text { indigestion, parasitic } \\
\text { infection, generally } \\
\text { healing }\end{array}$ & $\begin{array}{l}\text { Taken raw or boiled in } \\
\text { milk and can be } \\
\text { consumed as a tonic }\end{array}$ \\
\hline
\end{tabular}

Most of the plant materials sold are used in treating common ailments prevalent in the region. Plants are used to cure common diseases related to skin, cold, fever, cough, headache, diarrhoea, uterine problems, toothache, stomach ache, wounds, diabetes, rheumatism, asthma, dysentery, bone fractures, hair loss and poisoning. Most of these plant species were used in treating more than one disease. Most sought after medicinal plant among these are Viscum articulatum used in treating fractures, Aconitum beterophyllum and Swertia chirayita in treating fever, skin disease and cold and cough followed by Terminalia belirica, T. chebula and Phyllanthus emblica 
used for multiple purposes. Woodfordia fruticosa is quite popular in treating diarrhoea and dysentery which is quite prevalent in the hills.

Different parts of the plants are sold as plant based raw drugs. Among the various plant parts are subterranean parts (roots, bulbs, rhizomes and root tubers), flowers, fruits and seeds, barks and whole plant. In many cases, it was found that different parts of the same species were also used in treating different ailment. The pattern of plant part use is provided in Fig.1. Analysis of parts used indicates highest percentage of the plant raw drugs are sold in the form of dried root/rhizome/bulbs (16 species) constituting $41 \%$ followed by fruits and seeds (11species) with $28 \%$. Barks (5 species) with $13 \%$, flowers and whole plant (3 species each) with $8 \%$ each and heartwood (1 species) with $2 \%$ have been found (Figure 1 ).

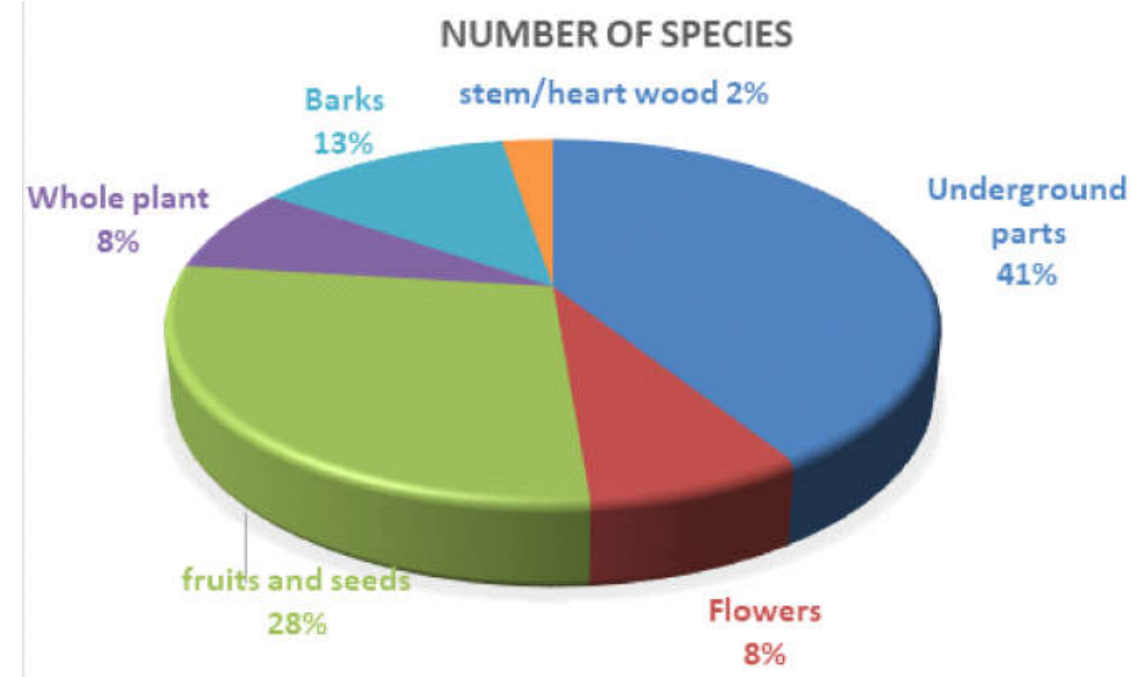

Figure 1. Plant parts of raw drugs sold in the market and their percentage

Many of the plant parts sold in the market fall under IUCN Red list. Nardostachys jatamansi is listed as critically endangered and Aconitum heterophyllum and, Swertia chirayita as endangered respectively at global level. Plants like Rawvolfia serpentina and Asparagus racemosus are assessed as endangered and Neopicrorbiza scrophularifflora as critically endangered in the state of West Bengal using IUCN criteria (Anonymous 2009). Allium wallichii is assessed as Endangered in the state of Sikkim (Ved et al. 2017). Most of these plants from alpine region are collected from across the Nepal border and sold elsewhere. Similar observation is also made by Olsen \& Helles (1997) and Pyakurel et al. (2017) in their study.

\section{CONCLUSION}

The study has revealed that 36 species of plant based raw drug are being sold in Darjeeling market. The plant materials are collected from the wild either by the seller themselves or are procured from the local people. Many of the plant species sold in the market are listed in the IUCN Red list. The parts used pattern indicates high degree of destructive collection as most of these species constitute the subterranean parts and whole plant parts. This information provides an intervention for their sustainable extraction.

\section{Acknowledgement}

The authors acknowledge and thank Plant based raw drug sellers - Jas Bahadur Limbu, Tshering Bhutia and S.K. Chettri who ekes their living by selling medicinal plants in Darjeeling town for 
sharing valuable information on the uses and mode of administration. We also thank the referee for his invaluable suggestion and necessary comments.

\section{LITERATURE CITED}

Anonymous 2009. Conservation Assessment and Management Prioritization for the Medicinal Plants of West Bengal. Singh R.R.P. \& Anupama (ed.) Published by Research Circle, Forest Department West Bengal and FLRHT, Banglore. Colour Xpress, Kolkata

Chhetri, D.R.; Basnet, D.; Chiu, P.F.; Kalikotay, S.; Chhetri, G. \& Parajuli, S. 2005. Current status of ethnomedicinal plants in the Darjeeling Himalaya. Current Science 89(2): 264 - 268.

Cowan, A.M. \& Cowan, J.M. 1929. The trees of North Bengal including shrubs, woody climbers, bamboos, palms \& tree ferns. Bengal Secretariat Book Depot, Calcutta.

Das, A.P. \& Mondal, S. 2003. Some Medicinal Plants of Darjeeling Hills. WWF-India, West Bengal State Office, Kolkata.

Ghosh, S. \& Tripathi, S.K. 2019. Ethnomedicinal and Threatened Medicinal Plants of Darjeeling Himalaya. In: Tripathi, S.K.; Upadhyay, K. \& Hegde, N (eds.). Medicinal Plants of India: Conservation and sustainable use. Today \& Tomorrow's Printers and Publishers, New Delhi 157 - 175. ISBN: 7988170196525.

Gierson, A.J.C. \& Long, D.G. 1984, 1987, 1991 \& 1999. Flora of Bhutan, Vol. 1, Part 2 \& 3, Vol. 2, Parts 1 \& 2. Royal Botanical Garden Edinburgh, UK and Royal Government of Bhutan

Gurung, B. 2002. The medicinal plants of Sikkim Himalaya. $1^{\text {st }}$ edition. Maples, Chakung, West Sikkim, India

Hamilton, A. \& Radford, E. 2007. Identification and conservation of Important Plant Areas for medicinal plants in the Himalaya. Project and Workshop report jointly organized by Plantlife International and Ethnobotanical Society of Nepal.

Olsen, C.S. \& Helles, F. 1997. Medicinal Plants, Markets and Margins in the Nepal Himalaya: Trouble in Paradise. Mountain Research and Development, 17(40): 363 - 374.

Pyakurel, D.; Bhattarai, I. \& Ghimire, S. 2017. Trade and conservation of medicinal and aromatic plants in western Nepal. Botanica Orientalis - Journal of Plant Science, 11: 27 - 37.

Rai, U. 2010. Population of eight medicinal plants of Darjeeling and Sikkim Himalayas. Pleione 4(2): $256-262$.

Ved, D.K; Suma, T.S.; Bhutia, T.G.; Ravikumar, K; Barve, V; Somashekar, B.S; Tandon, V.; Goraya, G.S.; Sumantha, M.V. \& Soumyashree, N. 2017. Conservation Assessment and Management Prioritization (CAMP) for the Wild Medicinal Plants of Sikkim. FRLHT-TDU, Bangaluru and SMPB-FEWMD. Gangtok. ISBN 978-93-84208-13-4.

Websites consulted:

www.plantlife.org.uk.

www.theplantlist.org

www.plantsoftheworldonline.org 